\title{
FORMULATION AND EVALUATION OF EFFERVECENT FLOATING TABLETS OF ANTIDIABETIC DRUG
}

\author{
*Anshuman Keshari, Dr. Pushpendra Kumar Tripathi, Arjita Srivashtava, Ratan Vishwas \\ Department of Pharmaceutics, Rameshwaram Institute of Technology\& Management Lucknow (Uttarpradesh), India \\ Received 01 Sep 2015; Review Completed 29 Sep 2015; Accepted 07 Oct 2015, Available online 15 Nov 2015
}

\begin{abstract}
The aim present investigation is Formulation and Evaluation of Effervescent Floating Tablets of antidiabetic drug. Gastric retention are such systems, which increase the gastric retention time of the dosage forms at the stomach and upper part of the small intestine and suitable for the drug having site-specific absorption from the above sites. The Metformin $\mathrm{HCl}$ an orally administered biguanide of BCS class-3 High solubility and low permeability, which is widely use in the management of and the type-II diabetes, is an oral anti- hyperglycemic agent, shows incomplete absorption from the gastrointestinal tract and from the gastrointestinal track and absolute bioavailability is 50-60\% with relatively short plasma half-life of $1.5-4.5$ hours. It was using different polymers studying of deferent factors affecting the floating behavior of the prepare tablets was of our goals and important target in this part. Gastro-retentive tablets of Metformin $\mathrm{HCl}$ were prepared by wet granulation method using HPMC K200M (Hydroxylpropyl methyl cellulose) micro crystalline cellulose PH 101, sodium bicarbonate, HPMC K100 (LV), Magnesium stearate, colloidal silicon dioxide. In this formulation HPMC K $200 \mathrm{M}$ was using different concentration. The Gastro-retentive tablet of Metformin $\mathrm{HCl}$ was evaluation of compression blend Angle of repose, Bulk density, tapped density, Drug compressibility study, Drug release rate, floating lag time etc. Result of our present study suggests that gastro-retentive tablets of Metformin $\mathrm{HCl}$ can be successfully designed to develop sustained release drug delivery which can reduce dosing frequency
\end{abstract}

Keywords: Effervescent system, gas generating system, gastro retentive drug delivery system, sustained drug release,

Metformin hydrochloride

\section{INTRODUCTION:}

The oral route is considered as the most promising route of drug delivery. Effective oral drug delivery may depend upon the factors such as gastric several physiological limitations such as variable gastrointestinal transit, because of variable gastric emptying leading to non-uniform absorption profiles, incomplete drug release and shorter residence time of the dosage form in the stomach. This leads to incomplete absorption of drug shaving absorption window especially in the upper part of the small intestine, as once the drug passes down the absorption site, the remaining quantity goes unabsorbed. The Gastric emptying of dosage forms in humans factors because of which wide inter and are affected by several intra-subject variations are observed ${ }^{1}$. Since many drugs are well absorbed in the upper part of the gastrointestinal tract, such high vari-ability may lead to non-uniform absorption and makes the bioavailability unpredictable. Hence a beneficial delivery system would be one which possesses the ability to control and prolong the gastric emptying time and can deliver drugs in higher concentrations to the absorption site (i.e. upper part of the small intestine). Metformin $\mathrm{HCl}$ is an orally administered biguanide derivative widely used in the treatment of non-insulin dependent diabetes mellitus. It improves the glycemic control by enhancing insulin sensitivity in liver and muscles. Metformin also has beneficial effect on several cardiovascular risk factors such as dyslipidemia, elevated plasma-plasminogen activator inhibitor, other fibrinolytic abnormalities, and hyper insulenimia, and insulin resisance ${ }^{2}$ Oral administration is the most convenient and preferred means of any drug delivery to the systematic circulation. Oral controlled release drug delivery have recently been of increasing interest in pharmaceutical field to achieve improved therapeutic advantages, such as ease of dosing administration, patient compliance and flexibility in formulation. Drugs that are easily absorbed from gastrointestinal tract (GIT) and have short half-lives are eliminated quickly from the systemic circulation. Frequent dosing of these drugs is required to achieve suitable therapeutic activity. To avoid this limitation, the development of oral sustained-controlled release formulations is an attempt to release the drug slowly into the gastrointestinal tract (GIT) and maintain an effective drug concentration in the systemic circulation for a long time.

*Address for correspondence: Anshuman Keshari Department of Pharmaceutics,

Rameshwaram Institute of Technology \& Management Lucknow (Uttarpradesh), India E-mail: anashumank59@gmail.com 
After oral administration, such a drug delivery would be retained in the stomach and release the drug in a controlled manner, so that the drug could be supplied continuously to its absorption sites in the gastrointestinal tract $(\mathrm{GIT})^{3}$. These drug delivery systems suffer from mainly two adversities: the short gastric retention time (GRT) and unpredictable short gastric emptying time (GET), which can result in incomplete drug release from the dosage form in the absorption zone (stomach or upper part of small intestine) leading to diminished efficacy of administered dose $^{4}$.

\section{MATERIAL AND METHODS}

Table 1: List of various chemical/regents used in project work

\begin{tabular}{|c|l|l|}
\hline Sr.No & Ingredient & Source \\
\hline 1 & Metformin HCl & Biocon limited \\
\hline 2 & Microcrystalline cellulose (Avicel PH 101) & FMC Biopolymer \\
\hline 3 & Methocel K 200 M(HPMC) & Colorcon \\
\hline 4 & Cabopol 971 P & Colorcon \\
\hline 5 & Povidone K-30 & BASF \\
\hline 6 & Methocel K 100 LV(HPMC) & Colorcon \\
\hline 7 & Methocel K 100 M (HPMC) & Colorcon \\
\hline 8 & Sodium bicarbonate & Merck \\
\hline 9 & Synpro Magnesium stearate & Ferro Industries \\
\hline 10 & Colloidal silicon dioxide (Aerosil 200 Pharma) & Evonik industries AG \\
\hline 11 & Eudragit ${ }^{\circledR}$ RL/PO & Evonik \\
\hline 12 & Eudragit ${ }^{\circledR}$ RL/PO & Evonik \\
\hline 13 & Tri ethyl citrate & Vertellus \\
\hline 14 & Talc & Signet \\
\hline 15 & Isopropyl alcohol & Sri tirumala Chemical \\
\hline 16 & Acetone & Avantor \\
\hline 17 & Acetonitrile & Avantor \\
\hline 18 & HCL & Sigma-Aldrich \\
\hline
\end{tabular}

Table 2: List of Equipment used for the study

\begin{tabular}{|c|l|l|l|}
\hline Sr.No & Equipment's & Manufacturer & Model No \\
\hline 1 & Weighing balance & Sartorius & GPA5202 \\
\hline 2 & Mechanical stirrer & Remi Motors & 5MHL PLU \\
\hline 3 & V-cone blender & Chamunda & CPM VB-50 \\
\hline 4 & Mini Tablet Compression machine & Kambert & KMP-D8-08 \\
\hline 5 & Portable Hardness tester & Electrolab & EH-01 \\
\hline 6 & Automated Tablet Friabilator & Electrolab & EF-2W \\
\hline 7 & Vernier Caliper & Mitutoyo & CD-8”CSX \\
\hline 8 & Moisture analyser & Sartorius & MA150 \\
\hline 9 & Tap density tester & Electrolab & ETD-1020 \\
\hline 10 & Electromagnetic sieve shaker & Electoral & ENS-8 PLUS \\
\hline 11 & Rapid Mixer granulator & Kevin & HSMG-10 \\
\hline 12 & Dissolution test apparatus & Electrolab & EDT-08LX \\
\hline 13 & Differential scanning calorimetry & Tzero ${ }^{\circledR}$ DSC & Q2000 (TA Instruments, \\
\hline 14 & Quadra-Co-Mill & Gansons Quadr & U-5 \\
\hline 15 & High performance liquid Chromatography (HPLC) & Waters and Agilent & Alliance and 1260 \\
\hline 16 & FTIR Spectrophotometer & Perkin Elmer & ------- \\
\hline 17 & Nuclear Magnetic Resonance & Bruker & AV300 \\
\hline 18 & Powder X-ray diffraction & Rigaku Ultima & -------- \\
\hline 19 & Oven & Thermolab & T00001000S \\
\hline 20 & Stability Chamber & Newtronic & DCM-30 \\
\hline & & & \\
\hline
\end{tabular}


Procedure of pre-optimization study

\section{Preparation of tablets by wet granulation technique}

Floating matrix tablets containing of Metformin $\mathrm{HCl}$ were prepared using wet granulation method using HPMC K 100 M, K $200 \mathrm{M}$ and carbopol $971 \mathrm{P}$ as polymer. All ingredients and d drug weight individually passed through sieve no 30, mixed and granulated with $10 \%$ solution of PVP K 30 in water. The wet mass was passed through the sieve no 16 and dried rapid dryer at $30^{\circ} \mathrm{C}$ for $25 \mathrm{~min}$ at $30 \mathrm{cfm}$ to control a final LOD of about NMT 2.0\% w/w. Dried granules were passed through the sieves no 40G using Ganson's Co-Mill and were mixed with weight quantity of sodium bicarbonate, lubricated with magnesium stearate and glidant colloidal silicon dioxide.

Compression force was kept constant throughout the study. Compression was carried out for final blend by using CADMAC $16 \times 9.5 \mathrm{~mm}$ oval shaped with deposed on upper punch (D tooling).

Table 3: Parameters in the RMG-(HSMG)

\begin{tabular}{|c|c|c|c|c|}
\hline Sr.no & Parameters & Time (Min) & Impeller (rpm) & Chopper (rpm) \\
\hline 1 & Dry Mix & 10 & 500 & NR \\
\hline 2 & Binder Addition & 1 & 500 & NR \\
\hline 3 & Kneading & 1 & 500 & 1000 \\
\hline
\end{tabular}

Table 4: Composition of floating tablets of Metformin $\mathrm{HCl}$

\begin{tabular}{|c|c|c|c|c|c|c|}
\hline Sr.No & Ingredients & \multicolumn{5}{|c|}{ Formula (mg/tab) } \\
\hline \multirow[t]{2}{*}{1} & \multirow[t]{2}{*}{ Metformin $\mathrm{HCl}$} & $\mathbf{F}_{1}$ & $\mathbf{F}_{2}^{*}$ & $\mathbf{F}_{3}$ & $\mathbf{F}_{4}$ & $\mathbf{F}_{5}$ \\
\hline & & 500 & 500 & 500 & 500 & 500 \\
\hline 2 & HPMC K $100 \mathrm{M}$ & 100 & 100 & 100 & --- & --- \\
\hline 3 & HPMC K $200 \mathrm{CR}$ & --- & --- & --- & 130 & 180 \\
\hline 4 & Corbopol $941 \mathrm{P}$ & 32 & 32 & 22 & --- & $\begin{array}{c}--- \\
\end{array}$ \\
\hline \multirow[t]{2}{*}{5} & Micro crystalline cellulose $\mathrm{pH} 101$ & 37 & 24 & 34 & 46 & 44 \\
\hline & Binder & & & & & \\
\hline 6 & PVP-30K & 10 & 10 & 10 & 10 & --- \\
\hline 7 & HPMC K 100 LV & --- & --- & --- & --- & 10 \\
\hline \multicolumn{7}{|c|}{ Extra granular Ingredients } \\
\hline 8 & Sodium bi carbonate & 7 & 20 & 50 & 50 & 50 \\
\hline 9 & Colloidal silicon dioxide & 7 & 7 & 7 & 7 & 8 \\
\hline 10 & Magnesium Stearate NF & 7 & 7 & 7 & 7 & 8 \\
\hline \multicolumn{2}{|r|}{ Tablet Weight: } & 700 & 700 & 730 & 750 & 800 \\
\hline
\end{tabular}

\footnotetext{
* Coating formulation no F2 $(10 \%)$
}

Table 5: Coating composition (10\%) formulation no F2

\begin{tabular}{|c|c|c|}
\hline S.NO. & INGREDIENT & WEIGHT ( gm) \\
\hline $\mathbf{1}$ & Eudragit RL/PO & 11.84 \\
\hline $\mathbf{2}$ & Eudragit RS/PO & 30.33 \\
\hline $\mathbf{3}$ & TEC & 4.04 \\
\hline $\mathbf{4}$ & Talc & 20.22 \\
\hline $\mathbf{5}$ & IPA & 201.64 \\
\hline $\mathbf{6}$ & Acetone & 146.65 \\
\hline $\mathbf{7}$ & Water & 18.33 \\
\hline
\end{tabular}

\section{Coating procedure:}

All ingredients were accurately weighted, Mixed manually desired quantity of Acetone and water, further added weighed quantity of TEC, stirrer for about 45 minutes by using mechanical stirrer and mixed weighed quantity of Talc in to above prepared solution stir for about 20 minutes by using mechanical stirrer (Coating solution-1). Mixed weighed quantity of Eudragit RL/PO and Eudragit RS/PO in to Isopropyl alcohol, stir for about 30 minutes by using mechanical stirrer (Coating solution-2). Mixed slowly coating solution-1 to coating solution-2 to prepare final coating solution and coating of formulation (F2) was done by using fully automatic pan coater ACG Coating QUEST-TC. 


\section{Procedure of Optimization Studies}

Doe optimization by $3^{2}$ central composite designs:

The project leads to a method for preparing an extended release tablet formulation of 500mg Metformin $\mathrm{HCl}$. A unique blend of matrix system was used as a base for retarded release of drug. Two different grades of hydroxypropylmethyl cellulose (HPMC K100 LV and
HPMC K $200 \mathbf{M}$ ) were mixed in different ratio to obtain a suitable matrix system for achieving the extended release profile of the said Metformin $\mathrm{HCl}$. There are two independent variables and three responses in the formulation designing process. A $3^{2}$ central composite design was employed for the purpose. Table 6: depicts the detailed composition of formulations prepared as per the optimization design.

Table 6: Independent Variables and Different Levels Selected for $3^{2}$ Central Composite Design

\begin{tabular}{|c|c|c|c|c|c|c|}
\hline Std & RUN & $\begin{array}{c}\text { Factor } 1 \\
\text { A: HPMC K } 100 \mathrm{LV} \\
(\mathrm{mg})\end{array}$ & $\begin{array}{c}\text { Factor } 2 \\
\text { B: HPMC K } 200 \mathrm{LV} \\
(\mathrm{mg})\end{array}$ & $\begin{array}{c}\text { Response } 1 \\
\text { Q1\% }\end{array}$ & $\begin{array}{c}\text { Response } 2 \\
\text { Q4 \% }\end{array}$ & $\begin{array}{r}\text { Response } 3 \\
\text { Q10\% }\end{array}$ \\
\hline 12 & 1 & 12.50 & 150.00 & 32 & 69 & 100 \\
\hline 9 & 2 & 12.50 & 150.00 & 32 & 69 & 100 \\
\hline 6 & 3 & 20.00 & 150.00 & 31 & 64 & 100 \\
\hline 1 & 4 & 5.00 & 80.00 & 34 & 68 & 92 \\
\hline 2 & 5 & 20.00 & 80.00 & 33 & 66 & 93 \\
\hline 5 & 6 & 5.00 & 150.00 & 31 & 64 & 92 \\
\hline 8 & 7 & 12.50 & 220.00 & 28 & 62 & 89 \\
\hline 13 & 8 & 12.50 & 150.00 & 28 & 69 & 100 \\
\hline 11 & 9 & 12.50 & 150.00 & 28 & 69 & 100 \\
\hline 10 & 10 & 12.50 & 150.00 & 28 & 69 & 100 \\
\hline 4 & 11 & 20.00 & 220.00 & 27 & 50 & 90 \\
\hline 7 & 12 & 12.50 & 80.00 & 31 & 67 & 100 \\
\hline 3 & 13 & 5.00 & 220.00 & 31 & 66 & 98 \\
\hline
\end{tabular}

Table 7: Composition of floating tablets of Metformin HCl

\begin{tabular}{|c|c|c|c|c|c|c|c|c|c|c|}
\hline Sr.No & Ingredient & \multicolumn{9}{|c|}{ Formulation Code (mg/tab) } \\
\hline & & F1 & F2 & F3 & F4 & F5 & F6 & F7 & F8 & F9 \\
\cline { 3 - 12 } 1 & Metformin HCl & 500 & 500 & 500 & 500 & 500 & 500 & 500 & 500 & 500 \\
\hline 2 & HPMC K 200 M & 80 & 150 & 220 & 80 & 150 & 220 & 80 & 150 & 220 \\
\hline 3 & MCC PH 100 & 169 & 99 & 29 & 161.5 & 91.5 & 21.5 & 154 & 84 & 14 \\
\hline & Binder & & & & & & & & & \\
\hline 4 & HPMC K 100 LV & 5 & 5 & 5 & 12.5 & 12.5 & 12.5 & 20 & 20 & 20 \\
\hline & $\begin{array}{c}\text { Extra granular } \\
\text { ingredients }\end{array}$ & & & & & & & & & \\
\hline 5 & Sodium bicarbonate & 50 & 50 & 50 & 50 & 50 & 50 & 50 & 50 & 50 \\
\hline 6 & $\begin{array}{c}\text { Colloidal silicon } \\
\text { dioxide }\end{array}$ & 8 & 8 & 8 & 8 & 8 & 8 & 8 & 8 & 8 \\
\hline 7 & Magnesium sterate NF & 8 & 8 & 8 & 8 & 8 & 8 & 8 & 8 & 8 \\
\hline & Table Wight: & 820 & 820 & 820 & 820 & 820 & 820 & 820 & 820 & 820 \\
\hline
\end{tabular}

\section{Pre-Compression Evaluation}

\section{Evaluation of Powder Blends}

\section{Bulk density:}

\section{Tapped Density:}

Tapped density was calculated from the formula below.

Tapped density $(\mathrm{g} / \mathrm{ml})=\frac{\text { Weight of the blend }}{\text { Tapped volume of the blend }}$

\section{Measures of Powder Compressibility:}

For poorer flowing materials, there are frequently greater inter-particle interactions, and a greater difference between the bulk and tapped densities were observed. These differences are reflected in the compressibility index and Hausner's ratio.
Bulk density was calculated from the formula given below.

$$
\text { Bulk density }(\mathrm{g} / \mathrm{ml})=\frac{\text { Weight of the blend }}{\text { Bulk volume of the blend }}
$$

Carr's compressibility index $=\frac{\text { Tapped denesity }- \text { bulk denesity }}{\text { Tapped denesity }} \times 100$

$$
\text { Hausner's ratio }=\frac{\text { Tapped denesity }}{\text { Bulk denesity }}
$$

\section{Post-Compression Evaluation}

1. Weight variation test: ${ }^{5}$

The USP weight variation test is run by weighing 20 tablets individually, calculating the average weight \& comparing the individuals tablet weight to the average. 


\section{Thickness and Diameter: ${ }^{6}$}

The thickness and diameter of the tablets were determined using a thickness gauge Vernier calipers model CD-8" CSX (Mitutoyo, New Delhi, India). Five tablets from each batch were used, and average values were calculated.

\section{Hardness: ${ }^{7}$}

Three tablets of each of the formulations were measured in the hardness test. The hardness was examined using a Hardness tester model EH-01 (Electrolab). The hardness was measured in $\mathrm{kg} / \mathrm{cm}^{2}$.

\section{Friability: ${ }^{8}$}

Then percentage friability was then calculated.

$$
\% \mathbf{F}=\frac{(\mathbf{W} \mathbf{1}-\mathbf{W} \mathbf{2})}{\mathbf{W} \mathbf{1}} \times 100
$$

$\% \mathbf{F}=$ Percentage friability

$\mathbf{W}_{\mathbf{1}}=$ Initial weight of tablets

W2= Final weight of tablets.

\section{Floating lag time and duration of floating: ${ }^{9}$}

Floating characteristics of the prepared formulations were determined using USP XXII paddle apparatus under sink conditions. $900 \mathrm{ml}$ of hydrochloric acid buffer $\mathrm{pH} 1.2$ was used as medium and the temperature was maintained to $37 \pm 0.5^{\circ} \mathrm{C}$ thought the study. The time between the introduction of tablet and its buoyancy on the gastric fluid required for the tablet to float on the gastric fluid (floating lag time) and the time during which dosages for measurement buoyant (duration of floating) were measured. The integrity of the test tablets was observed visually during study.

\section{Effect of Hardness on Buoyancy Lag Time ${ }^{10}$}

Formulation F1 to F5 was selected to study the effect of hardness on buoyancy lag time. The tablets of batch 6 were compressed at different compression pressures to get the hardness of $5 \mathrm{~kg} / \mathrm{cm} 2,6 \mathrm{~kg} / \mathrm{cm} 2,7 \mathrm{~kg} / \mathrm{cm} 2$, $8 \mathrm{~kg} / \mathrm{cm} 2$ and $9 \mathrm{~kg} / \mathrm{cm} 2$. The tablets were evaluated for buoyancy lag time. The method was same as mentioned in determination of lag time.

\section{In-vitro swelling study ${ }^{11}$}

Tablets were weighed individually and placed separately in basket of dissolution medium containing hydrochloric acid buffer ( $\mathrm{pH} 1.2$ ) solutions $900 \mathrm{ml}$ at $37 \pm 0.5^{\circ} \mathrm{C}$. At 12 hours, the tablets were withdrawn from the basket and blotted with tissue paper to removed excess surface water and the swollen tablets were reweighed on analytical balance. Swelling index (SI) of tablets was calculated using the following formula:

$$
\% \text { Swelling Index }=\frac{\text { Wet weight }- \text { Dry weight }}{\text { Wet weight }} \times 100
$$

\section{In - Vitro Drug Release Studies}

In-vitro dissolution studies were carried out in USP type-I (Basket) tablet dissolution apparatus using 900ml hydrochloric acid buffer $\mathrm{pH} 1.2$ as dissolution media. The basket was rotated at $100 \mathrm{rpm}$ and the temperature was maintained at $37 \pm 0.5^{\circ} \mathrm{C}$ throughout the study. Atprede termined time intervals $10 \mathrm{~mL}$ of the samples were withdrawn by means of an auto sampler machine with a pre filter. The volume withdrawn at each interval was replaced with same quantity of fresh dissolution medium maintained at $37 \pm 0.5^{\circ} \mathrm{C}$. The samples were analyzed for drug releases by measuring the absorbance at $255 \mathrm{~nm}$ using HPLC method.

\section{RESULTS AND DISCUSSION:}

Particle Size Analysis of Metformin HCl:

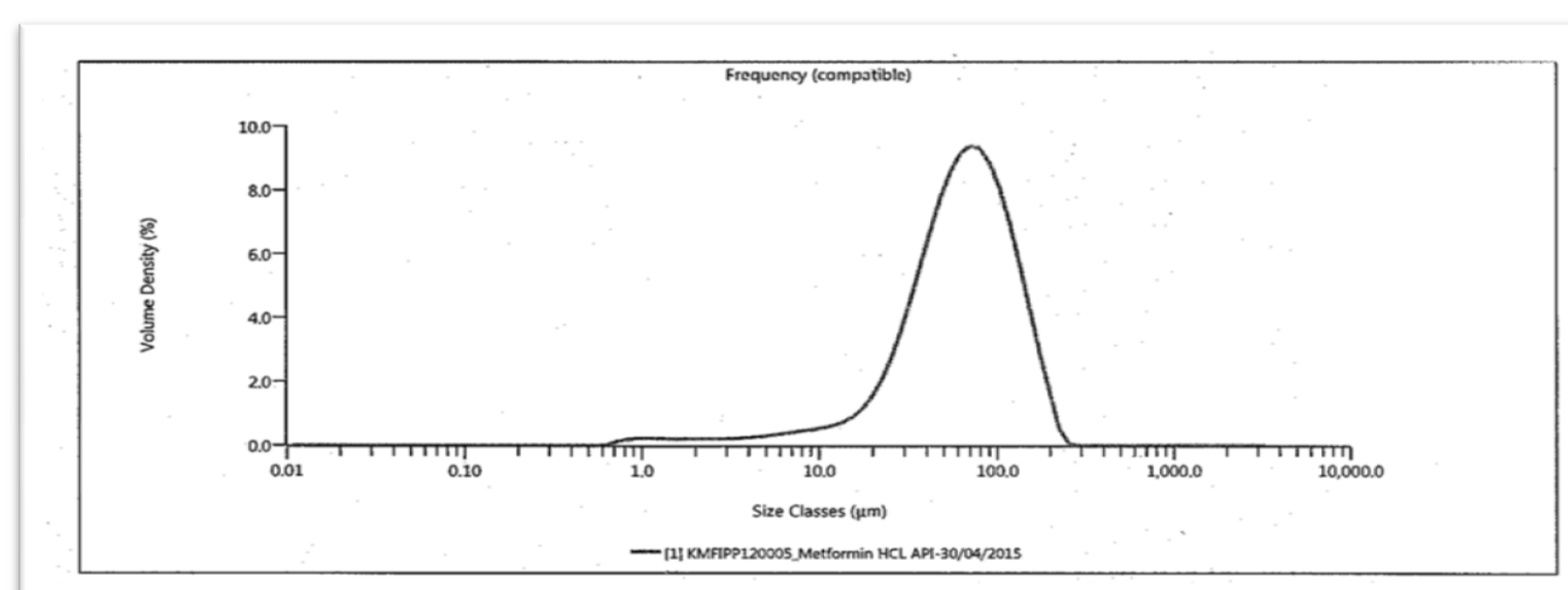

Figure 1: Particle size distribution

The flow properties of powders are dependent upon the particle size distribution as well as particle shape. Asymmetric particles have poor flow characteristics and hence granulation techniques are used to convert blends of drug and other additives into particles of uniform size having good flow properties. 


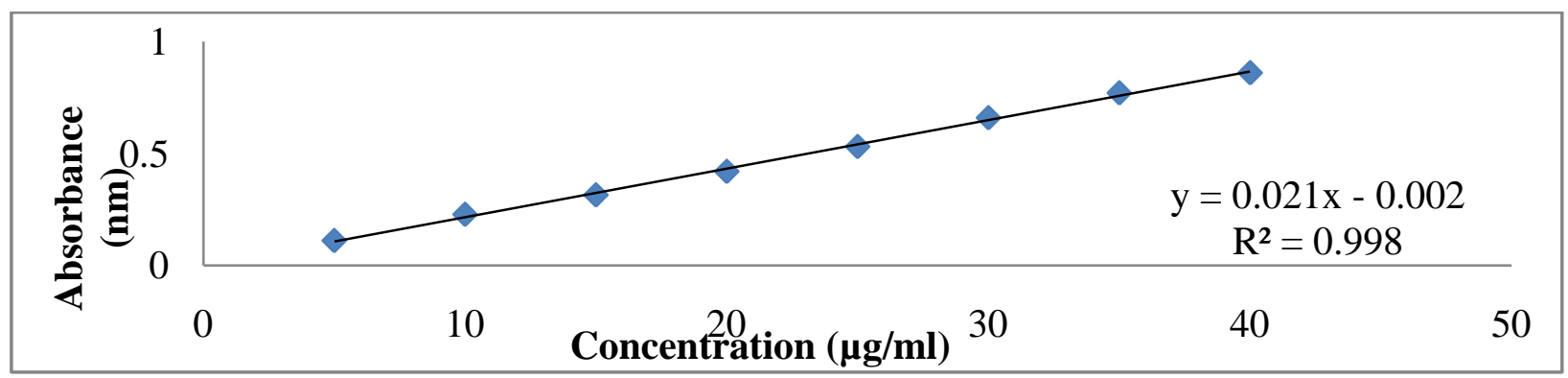

Figure 2: Preparation of Standard Curve of Metformin HCl

Linearity plot of Metformin $\mathrm{HCl}$ in the concentration range of 5-40 $\mu \mathrm{g} / \mathrm{ml}$ were evaluated. Linear absorbance versus concentration gives regression equation; $\mathrm{Y}=0.0217 \mathrm{x}-0.002$, with a correlation coefficient $\left(\mathrm{r}^{2}\right)$ of more than 0.99 in $0.1 \mathrm{~N}$ $\mathrm{HCl}$.

Fourier transform infrared spectroscopy:

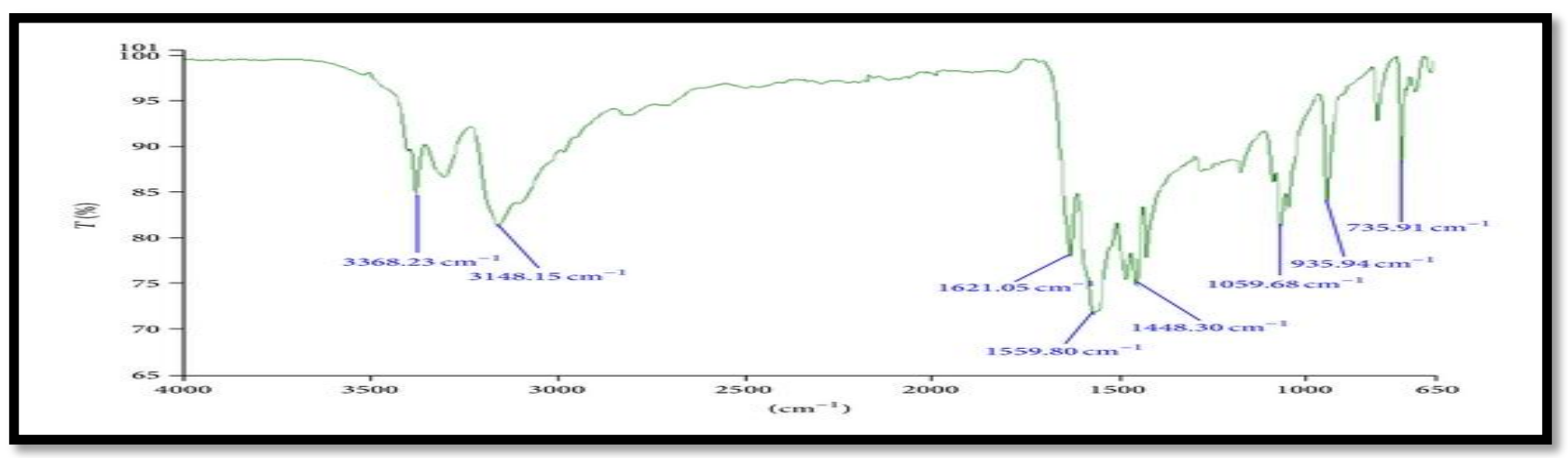

Figure 3: FT-IR spectrum standard of Metformin HCl

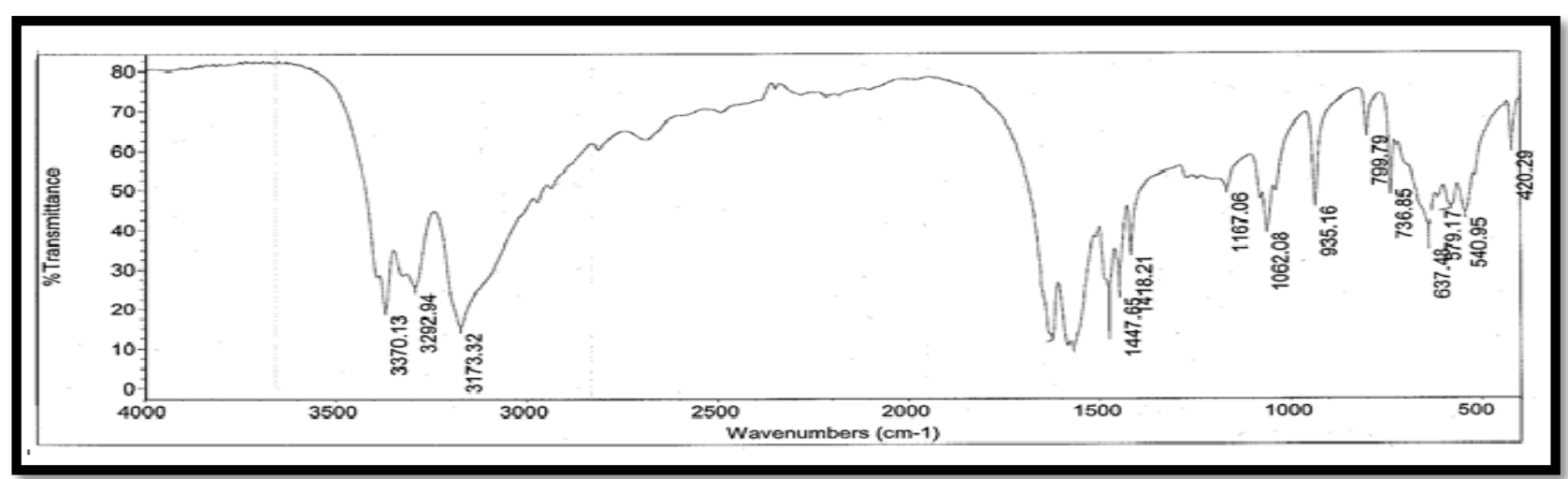

Figure 4: FT-IR spectrum of Metformin HCl

Nuclear magnetic resonance spectroscopy:

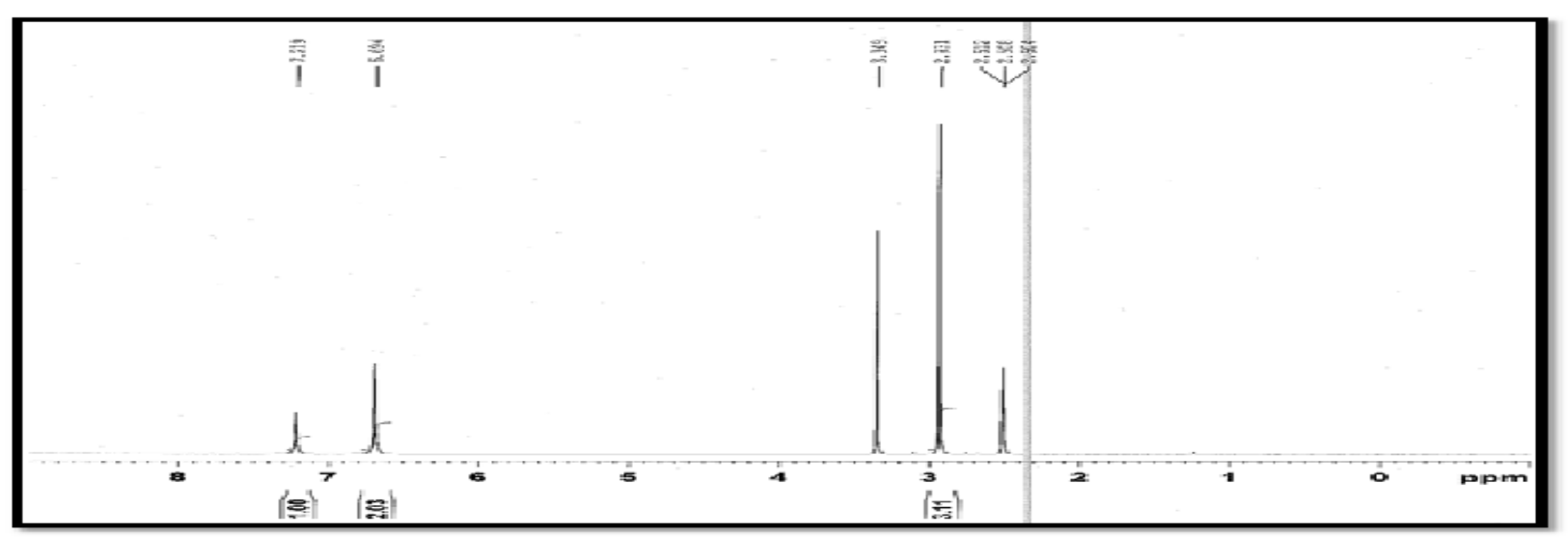

Figure 5: Nuclear magnetic resonance spectroscopy Ref. STD Metformin HCl 


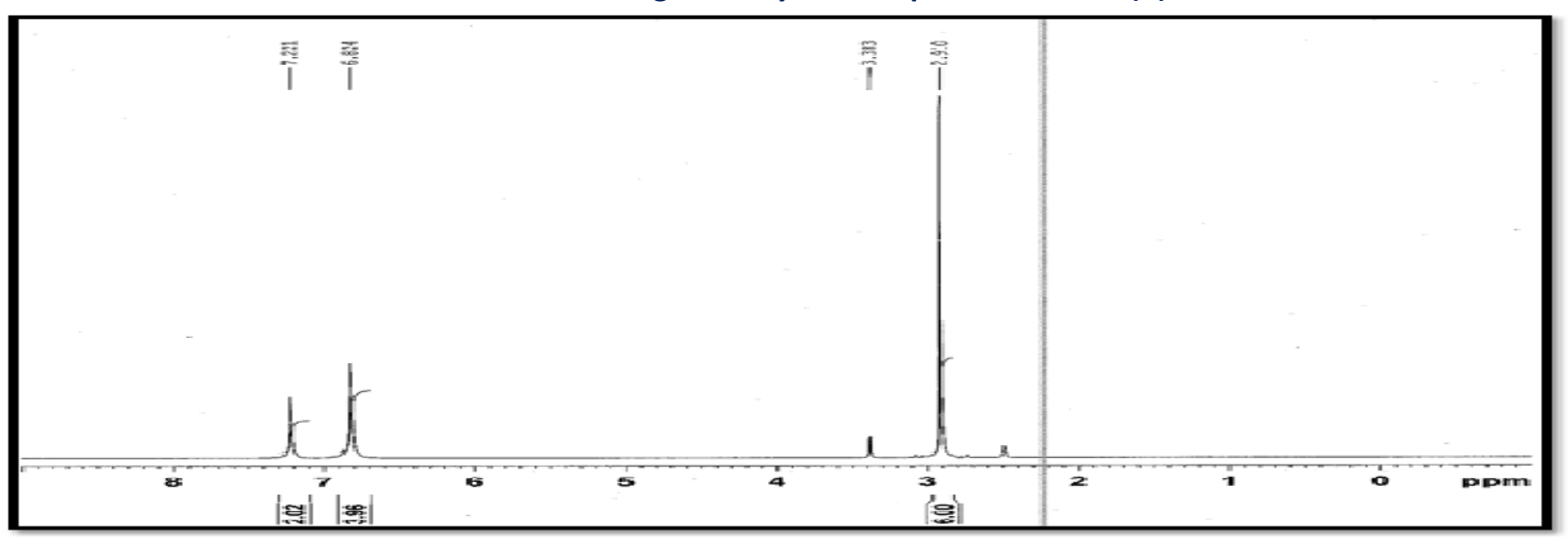

Figure 6: Nuclear magnetic resonance spectroscopy Ref. STD Metformin HCIMASS

\section{Mass Spectroscopy of Metformin HCl}

Because of their low stabilities in the ion trap detector, these product ions $(\mathrm{m} / \mathrm{z}=60.4$ for Metformin $\mathrm{HCl})$ are unsuitable for Quantitation of Metformin $\mathrm{HCl}$. Therefore, the isolated precursorions ( $\mathrm{m} / \mathrm{z}=130.2$ for Metformin $\mathrm{HCl}$ are selected for quantitative analysis without any fragmentation.

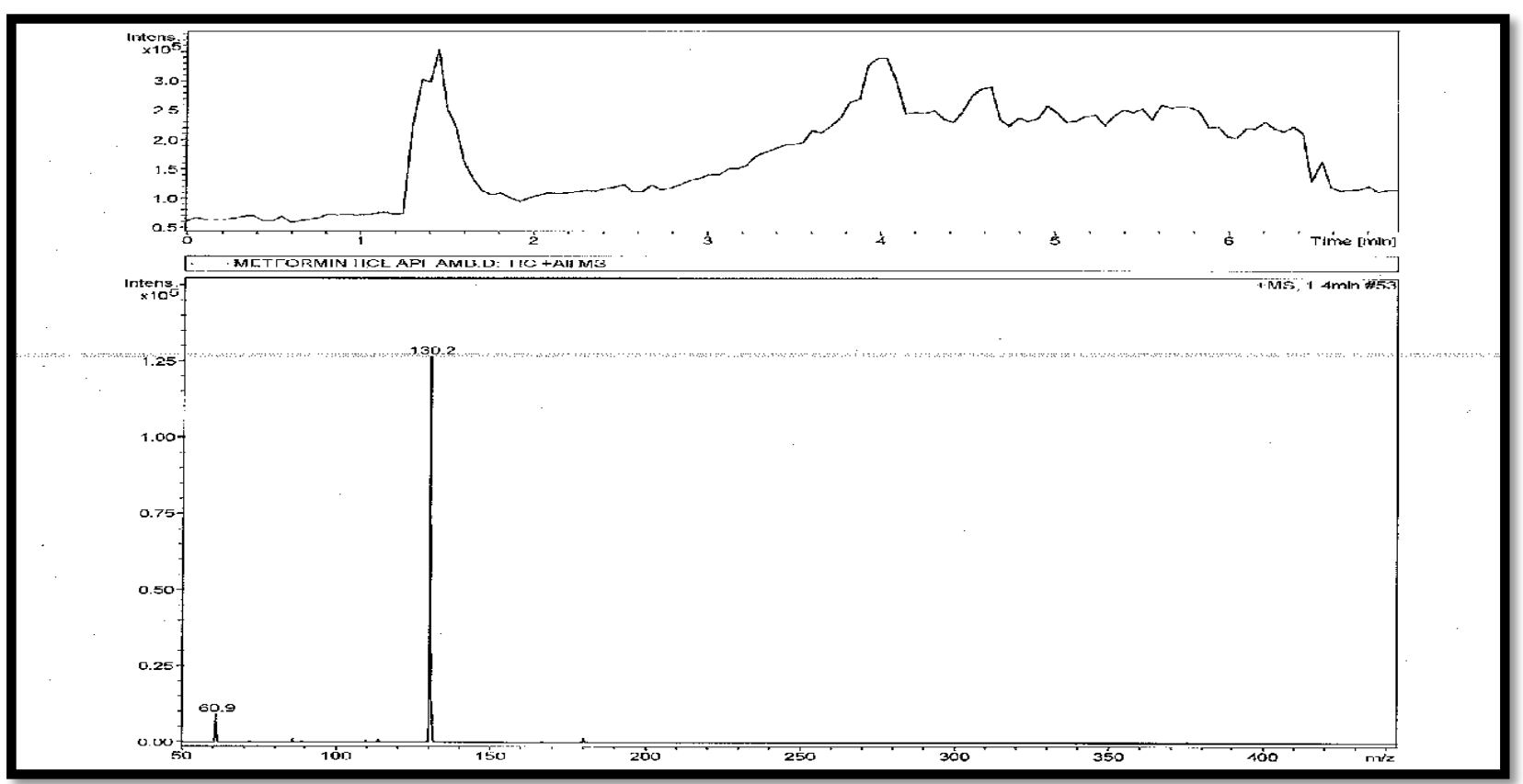

Figure 7: Mass Spectroscopy of Metformin HCl

\section{POWDER X-RAY DIFFRACTOMETRY}

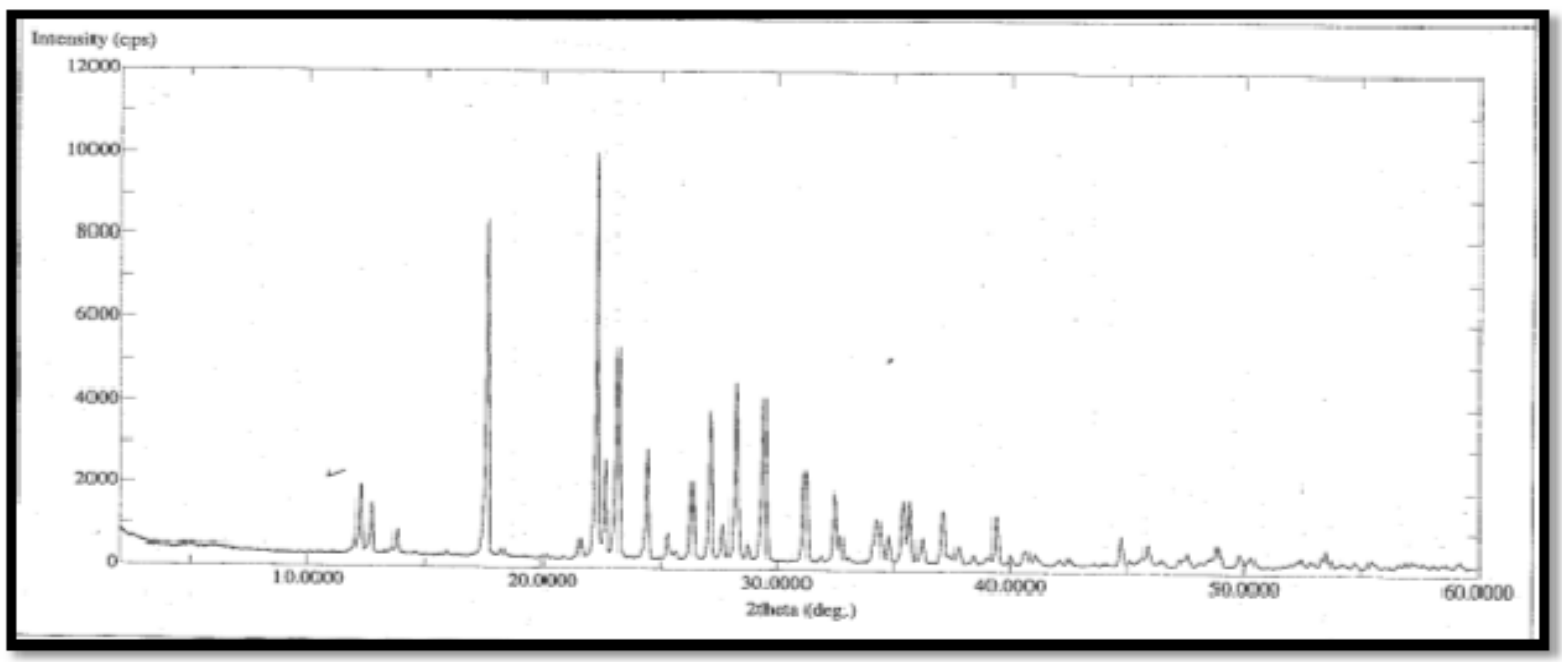

Figure 8: X- ray Diffraction graph of Ref. Std Metformin HCl 


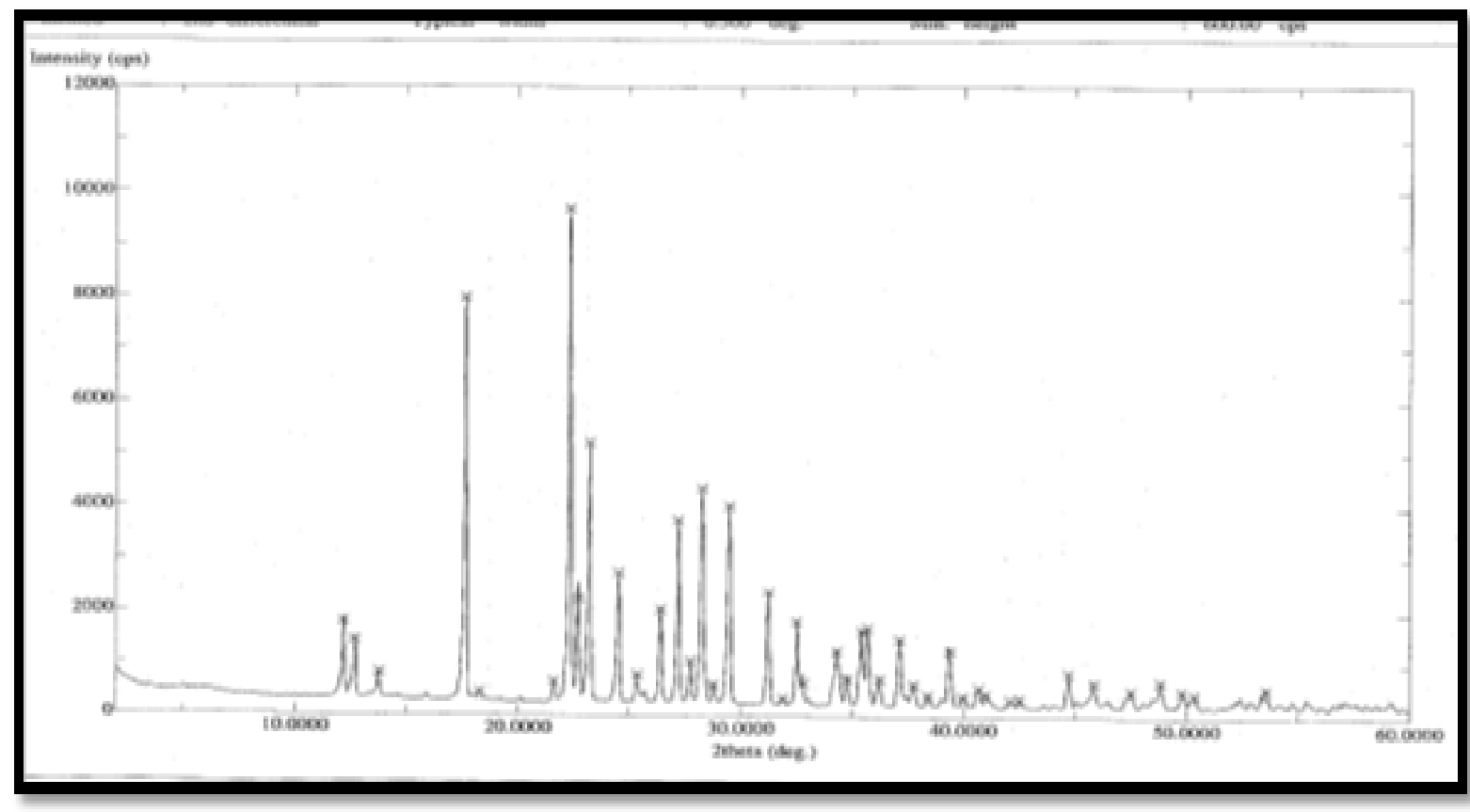

Figure 9: X- ray Diffraction graph of Metformin HCl

X-ray diffraction study of pure drug was carried out and its high intensity diffraction peaks at $2 \theta$ showed sharp peaks as similar to standard Metformin $\mathrm{HCl}$, both Pre-Optimization Studies

Evaluation of the Metformin $\mathbf{H C l}$ : Physical evaluation of the Drug

The API of were tested by various studies including bulk density $0.45 \mathrm{gm} / \mathrm{ml}$ ), tapped density $0.56 \mathrm{gm} / \mathrm{ml}$, Hausner's ratio 1.24 and Carr's index $19.64 \%$ ). All the results showed very-very poor flow property.
PXRD pattern showing crystalline nature as showed in figure $(8,9)$.

Table 8: Metformin HCl Characterization

\begin{tabular}{|c|c|c|}
\hline Sr.No & Characteristics & Results \\
\hline 1 & Physical Appearance & Off-White Powder \\
\hline 2 & Bulk Density & $0.45 \mathrm{gm} / \mathrm{ml}$ \\
\hline 3 & Tap Density & $0.74 \mathrm{gm} / \mathrm{ml}$ \\
\hline 4 & $\begin{array}{c}\text { Carr's Compressibility } \\
\text { Index }\end{array}$ & 38.64 \\
\hline 5 & Hausner's Ratio & 1.24 \\
\hline 6 & Melting Point & 222 to $226^{\circ} \mathrm{C}$ \\
\hline
\end{tabular}

\section{Pre-Compression Evaluation}

Table 9: Pre-compression parameters for formulations F1-F5

\begin{tabular}{|c|c|c|c|c|c|}
\hline Sr.No & Batch No & $\begin{array}{c}\text { Bulk Density } \\
(\mathbf{g} / \mathbf{m l})\end{array}$ & $\begin{array}{c}\text { Tapped Density } \\
(\mathbf{g} / \mathbf{m l})\end{array}$ & Carr's Index & Hausner's Ratio \\
\hline 1 & F1 & 0.519 & 0.65 & 20 & 1.25 \\
\hline 2 & F2 & 0.64 & 0.74 & 13.51 & 1.1 \\
\hline 3 & F3 & 0.59 & 0.71 & 16.90 & 1.22 \\
\hline 4 & F4 & 0.25 & 0.64 & 19.93 & 1.24 \\
\hline 5 & F5 & 0.56 & 0.66 & 15.06 & 1.17 \\
\hline
\end{tabular}

\section{Post-Compression Evaluation}

Table 10: Post compression parameters for formulations F1-F5

\begin{tabular}{|c|l|c|c|c|c|c|}
\hline Sr.no & Formulation code & F1 & F2 & F3 & F4 & F5 \\
\hline 1 & Thickness $(\mathrm{mm})$ & 6.45 & 6.42 & 6.82 & 5.12 & 5.75 \\
\hline 2 & Hardness $\left(\mathrm{Kg} / \mathrm{cm}^{2}\right)$ & 13.5 & 15.5 & 14.6 & 13.9 & 13.5 \\
\hline 3 & Friability $(\%)$ & 0.742 & 0.234 & 0.342 & 0.782 & 0.740 \\
\hline 4 & Weight Variation $(\mathrm{mg})$ & 0.12 & 0.34 & 0.56 & 0.54 & 0.67 \\
\hline
\end{tabular}


Floating Lag Time and Duration Of Floating

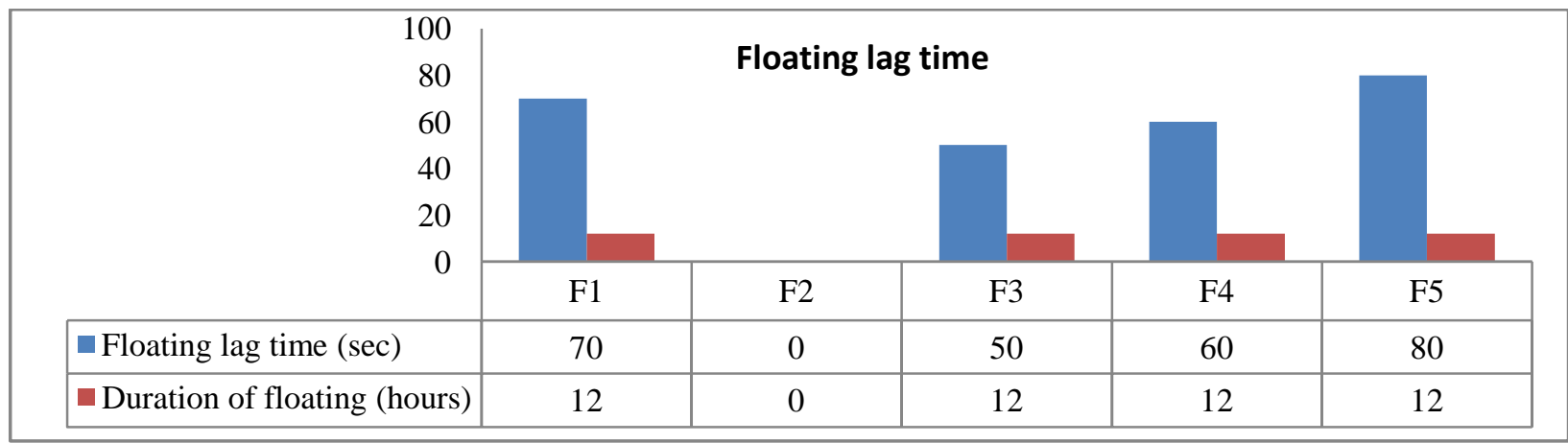

Figure 10: Floating lag time of various formulations

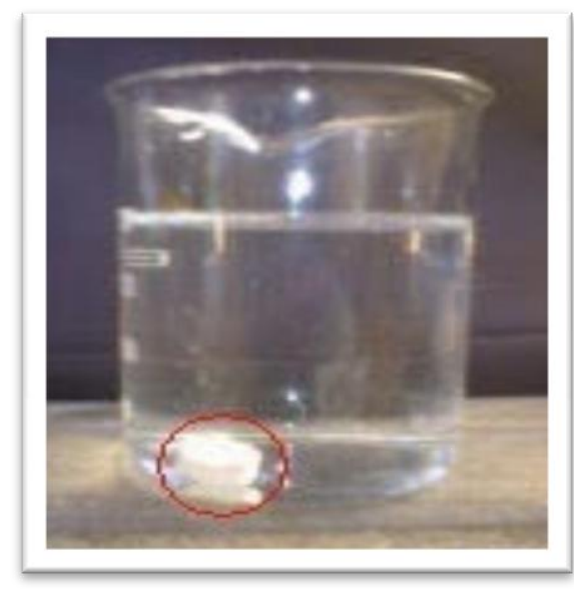

(a) At Initial Time

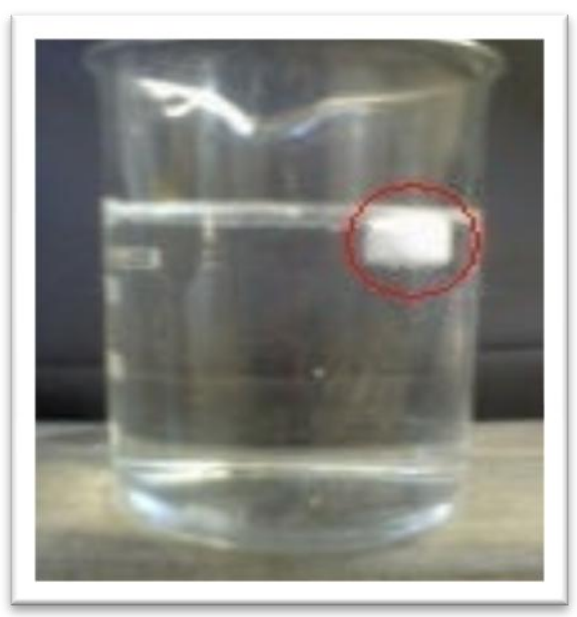

(c) After 70 Seconds

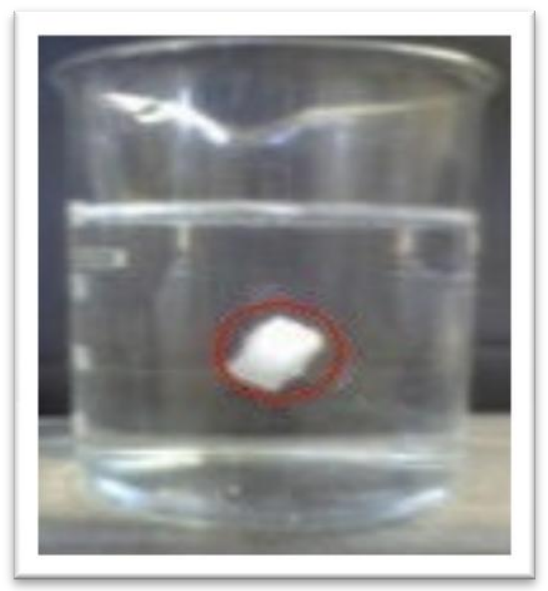

(b) After 50 Seconds

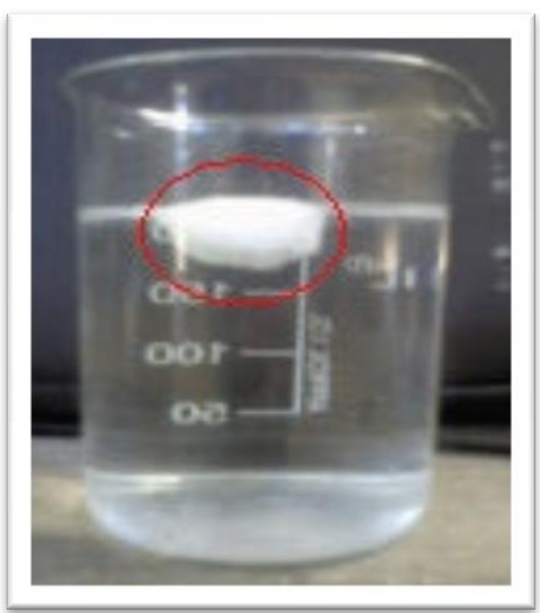

(d) After 12 hours

Figure 11: (a, b, c, d): Determination of Floating Time and Floating Lag Time

Studies to determine the Floating lag time and duration of floating of various formulations were carried out and the result indicated that floating lag time for all the tablets was within 0-4 minute after immersion into gastric media and duration of floating was greater than 12 hours for all batches. The effect of hardness on buoyancy lag time was studied and results indicated that with increasing the hardness, lag time also increased.

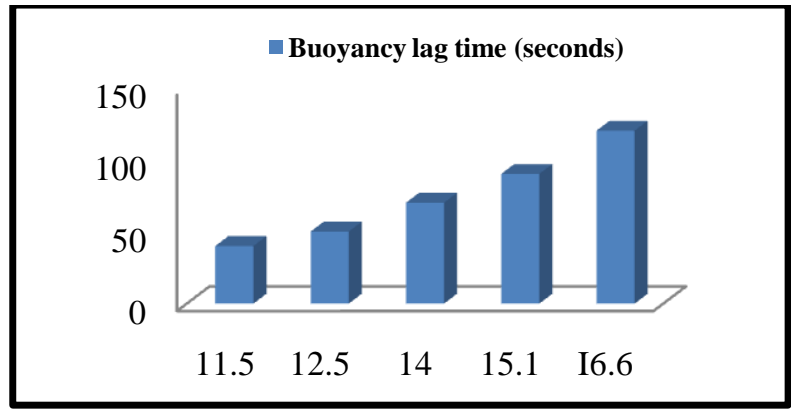

Figure 12: Effects of hardness on buoyancy lag time 


\section{IN VITRO DISSOLUTION TEST}

The dissolution profile of all batches (F1 to F5) Prepared by High Shear Mixer Granulator and Marketed formulation in hydrochloric acid $(1.2 \mathrm{pH})$ and results are reported in following tables:

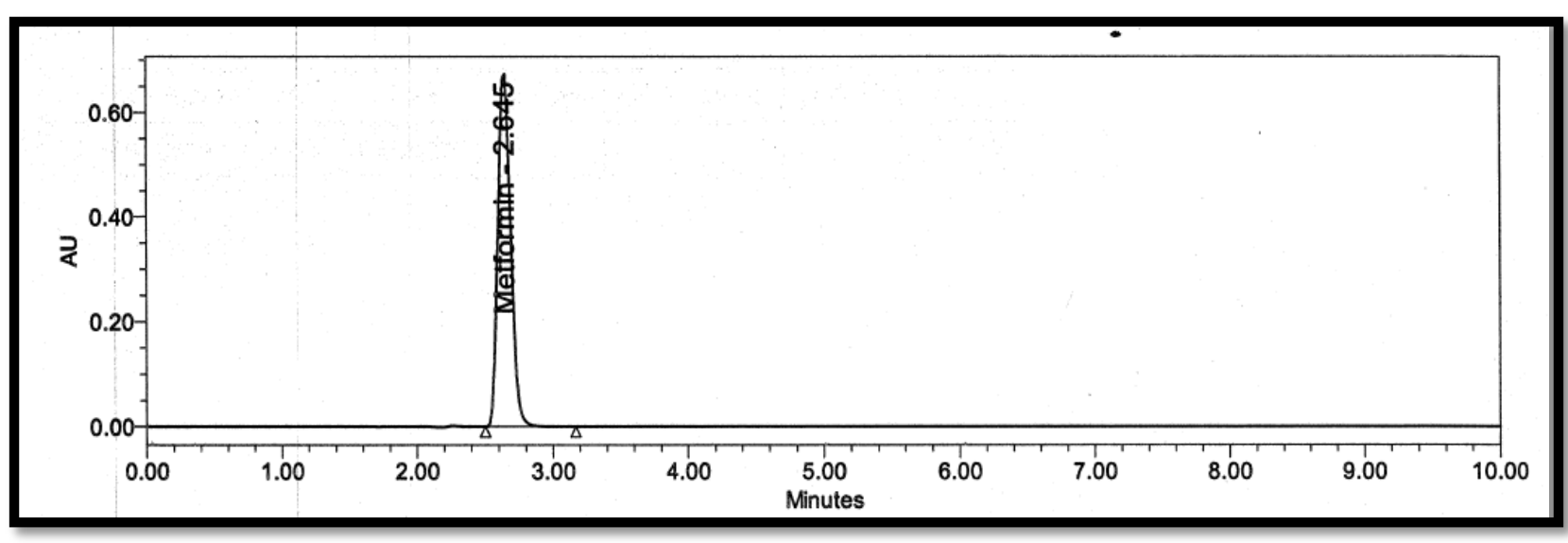

Figure 13: Specimen Chromatogram of Metformin HCl Standard

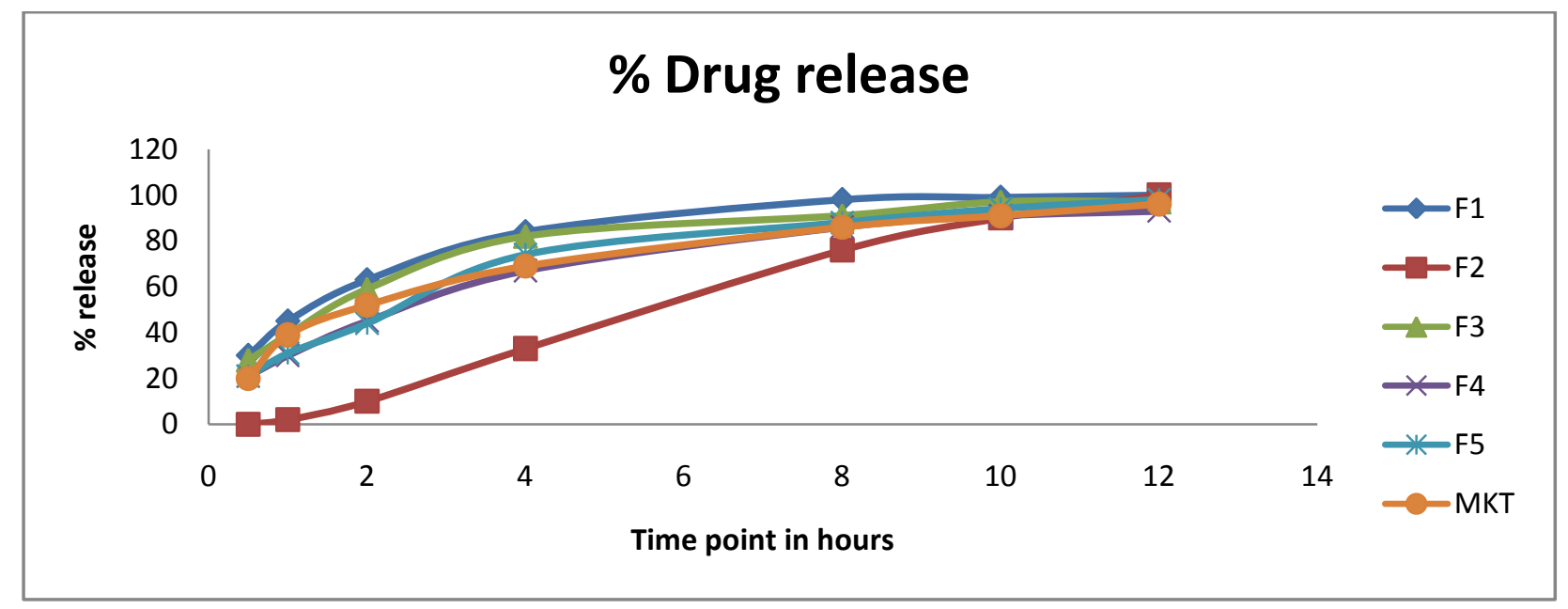

Figure 14: In-vitro drug release profiles graph

Prototype gastroretentive formulation Prepared by High Shear Mixer Granulator and Marketed extended release formulation in hydrochloric acid $(1.2 \mathrm{pH})$ compared and it was realized that formulation F5 shown similar release profile as compared to others. Coated F2 formulation profile was much slower at initial time point therefore coating technique was discouraged further optimization.

DOE OPTIMIZATION BY $3^{2}$ CENTRAL COMPOSITE DESIGN

PRE-COMPRESSION EVALUATION

Table 11: Pre-compression parameters for formulations F1-F9

\begin{tabular}{|c|c|c|c|c|c|}
\hline Sr.No & Batch No & $\begin{array}{c}\text { Bulk Density } \\
(\mathbf{g} / \mathbf{m l})\end{array}$ & $\begin{array}{c}\text { Tapped Density } \\
(\mathbf{g} / \mathbf{m l})\end{array}$ & Carr's Index & Hausner's Ratio \\
\hline 1 & F1 & 0.473 & 0.602 & 21 & 1.27 \\
\hline 2 & F2 & 0.551 & 0.674 & 18.24 & 1.22 \\
\hline 3 & F3 & 0.483 & 0.59 & 20.67 & 1.22 \\
\hline 4 & F4 & 0.491 & 0.619 & 19.67 & 1.26 \\
\hline 5 & F5 & 0.49 & 0.61 & 13.32 & 1.24 \\
\hline 6 & F6 & 0.514 & 0.593 & 15.48 & 1.15 \\
\hline 7 & F7 & 0532 & 0.633 & 10.68 & 1.11 \\
\hline 8 & F8 & 0.56 & 0.627 & 16.45 & 1.20 \\
\hline 9 & F9 & 0.457 & 0.549 & & \\
\hline
\end{tabular}


Floating Lag Time and Duration Of Floating

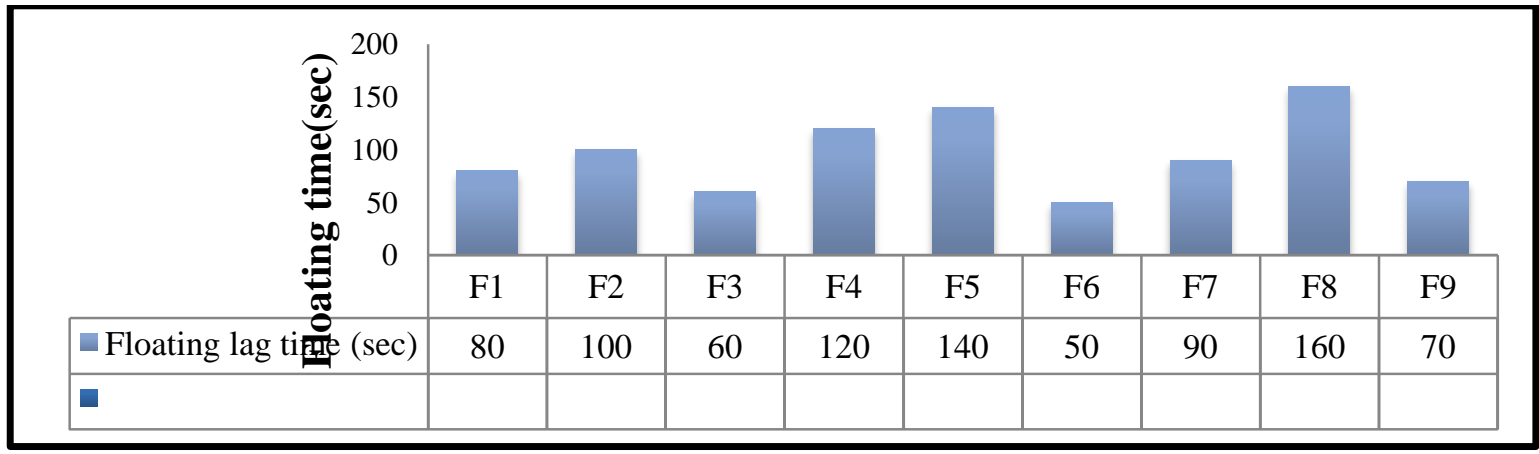

Figure 15: Determination of Floating Time and Floating Lag Time

Studies to determine the Floating lag time and duration of floating of various formulations were carried out and the results indicated that floating lag time which was observed for all the tablets was within 0-4 minute after immersion into gastric media and duration of floating was greater than 12 hours for all batches.

In Vitro Dissolution Test: The dissolution profile of all batches (F1 to F9) Prepared for DOE optimization and Marketed formulation in hydrochloric acid $(1.2 \mathrm{pH})$ and results are reported in following tables.

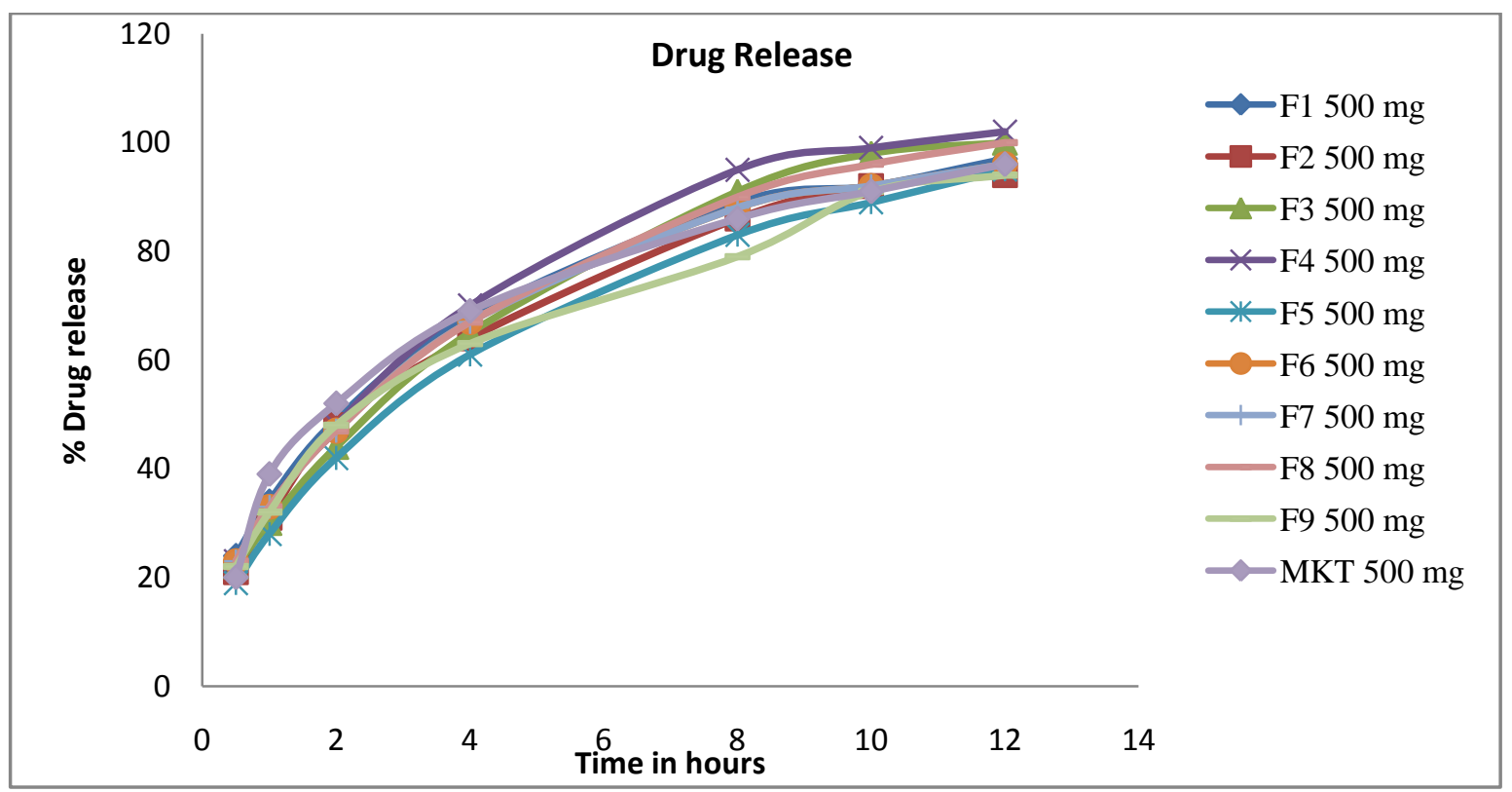

Figure 16: In-vitro drug release profiles of various formulations (F1 to F9 and MKT formulation)

Dissolution profile of DOE optimized gastroretentive formulation (F1-F9) and Marketed extended release formulation in hydrochloric acid $(1.2 \mathrm{pH})$ compared and it was realized that all formulation (F1-F9) shown similar release profile as compared with Marketed extended release formulation, hence out of all formulation composition any of formulation can be chosen for further commercial scalability and production. From DOE optimization it also proves robustness range of process.

Assay (BY HPLC) OF Metformin HCl Tablets

Table 12: Assay (By HPLC) of Metformin HCl Tablets

\begin{tabular}{|c|c|c|c|}
\hline Sr.no & Formulation & Area & \% Assay \\
\hline 1 & F1 & 2045019 & 99.10 \\
\hline 2 & F2 & 1966006 & 95.27 \\
\hline 3 & F3 & 1970934 & 95.51 \\
\hline 4 & F4 & 1982262 & 96.06 \\
\hline 5 & F5 & 2063604 & 100.00 \\
\hline 6 & F6 & 1862677 & 90.26 \\
\hline 7 & F7 & 1918276 & 92.96 \\
\hline 8 & F8 & 1953795 & 94.64 \\
\hline 9 & F9 & 2072338 & 100.42 \\
\hline
\end{tabular}


Average standard - 2063511.6

Assay result of all formulation were observed in between (90 to 110\%) of range.

\section{SELECTION OF THE OPTIMIZED FORMULATION}

The optimized formulation was selected by trading off the various responses. Fig. 17

Depicts the overlay plot showing the location of the optimized formulation.

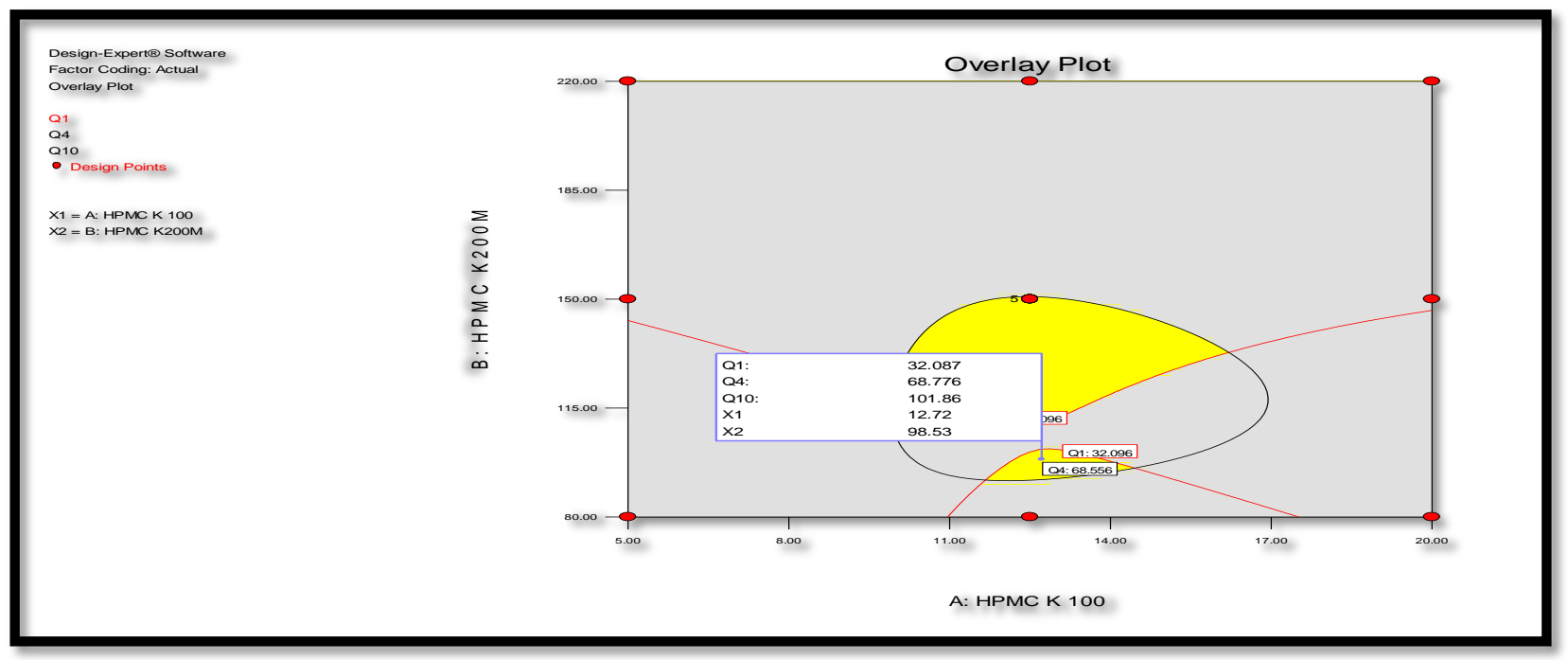

Figure 17: Selection of the optimized formulation

In vitro dissolution test of final formulation:

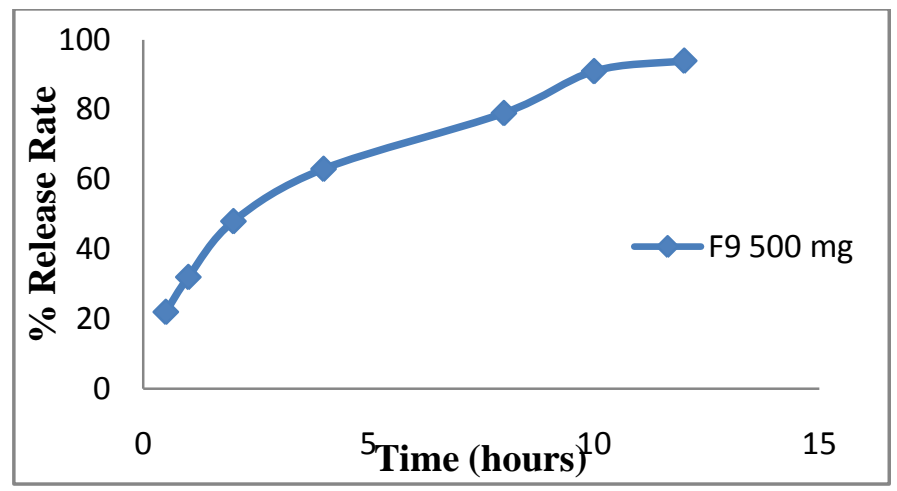

Figure 18: In-vitro drug release profiles of final formulation

Accelerated stability study of optimization formulation batch

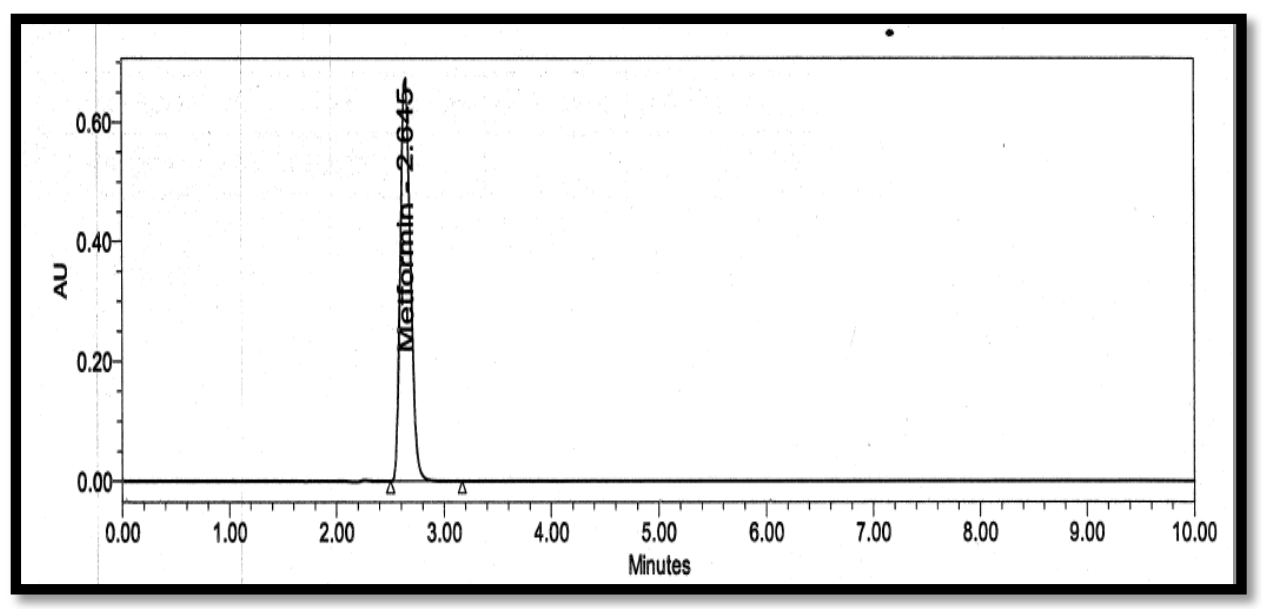

Figure 19: Specimen Chromatogram of Metformin HCl Standard 


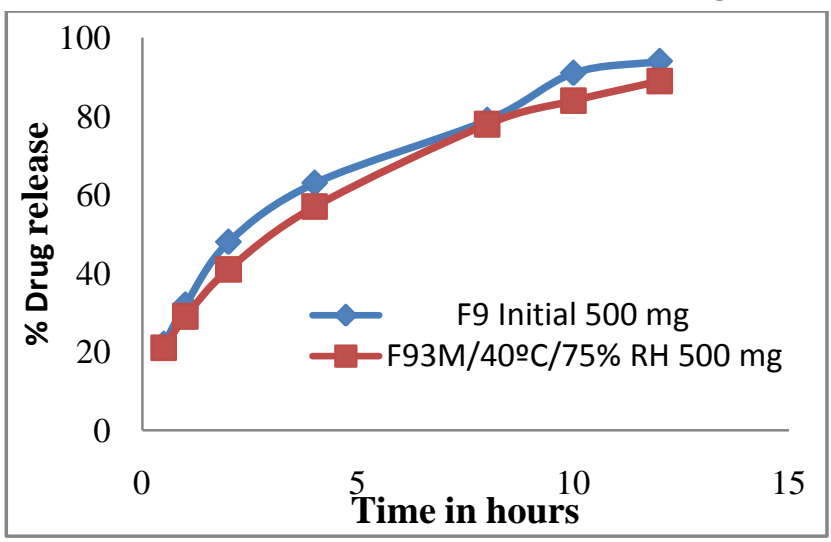

Figure 20: In-Vitro Drug release Stability studies

There is no significant fall observed in drug release profile of formulation F9 compared in initial and 3 month accelerated stability condition.

\section{CONCLUSION}

The main aim of the present dissertation was to develop novel Floating extended release formulation of Metformin $\mathrm{HCl}$ which is targeted to release drug till 12 hours at gastric region and compared the in-vitro similarity of novel formulation with already existing Marketed extended release formulation of Metformin $\mathrm{HCl}$, which releases drug in intestinal region. Thus from the data obtained, it can be concluded that:

Gastroretentive dosage form of an antidiabetic drug of Metformin $\mathrm{HCl}$ formulated as an approach to increase gastric residence time and thereby minimizing hepatic extraction ratio followed by dangerous side effects. It was an effort to introduced sodium bicarbonate as effervescent agent in matrix based tablet, which tends to create buoyancy in formulation at gastric site, results tablet start floating in gastric region for sustained time period, thus release of drug at site of gastric mucosa in sustained way. Among the polymers used to improve the gastric residence, cellulose Polymers HPMC K100M, HPMC K200CR, showed better control over drug release than Carbopol 941P. Gastroretentive dosage form (Novel extended release formulation) are claiming to advantage to reduce dosing frequency over conventionally available IR formulation of $500 \mathrm{mg}, 850$ $\mathrm{mg}$ and $1000 \mathrm{mg}$ recommended to two to three times daily leads to multiple dosing and patient incompliance as well as Potential side effects. Gastroretentive dosage form (Novel extended release formulation) is claiming to enhanced bioavailability and absorption of drug at site of gastric region.

\section{ACKNOWLEDGEMENTS}

I take it privilege sincerely express my deep sense of gratitude and thanks to guide Dr. Pushpendra Kumar Tripathi(Director of Pharmacy), Department of pharmaceutical, Rameshwaram Institute of Technology, whose meticulous guidance, valuable suggestion and constant motivation enabled me to complete this dissertation. The authors are thankful to Biocon Research Limited (Bangalore) for providing reference standards for permission as well as providing all facilities to complete this research work.

\section{REFERENCES:}

1. Rouge, N., Buri. P., Doelker, E., "Drug absorption sites in the gastrointestinal tract and dosage forms for site-specific delivery”, Int. J. Pharm., 1996, 136, 117-139

2. Dunn, C. J.; Peters D. H. Metformin. A review of its pharmacological properties and therapeutic use in non insulindependant diabetes mellitus. Drugs 1995, 49 (5), 721 749.

3. Streubel A, Siepmann J, Bodmeier R. Gastroretentive drug delivery system. Expert Opin Drug Deliv 2006; 3(2): 217- 33.

4. Iannucelli V, Coppi G, Bernabei MT, Camerorni R. Air compertment multiple-unit system for prolonged gastric residence. Part-I. Formulation study. Int J Pharm 1998; 174: 47-54.

5. The United States pharmacopoeia XX/National formulary XV U.S. Pharmacopoeial convention, Rock-ville, MD, 1980; pg 958,990.

6. Lachman, L.; Lieberman, H.A.; Lachman, kaling, J.L. The theory and practice of industrial pharmacy, $3^{\text {rd }}$ ed., Varghese Publishing House, Bombay, 1987; pg 296. 